\title{
Flower, Fruit, and Petiole Color of American Beautyberry (Callicarpa americana L.) Are Controlled by a Single Gene with Three Alleles
}

\author{
Ryan N. Contreras ${ }^{1,4}$ \\ Department of Horticulture, Oregon State University, 4017 Agricultural and \\ Life Sciences Building, Corvallis, OR 97331
}

John M. Ruter ${ }^{2}$

Allan Armitage Professor of Horticulture, Department of Horticulture, University of Georgia, 327 Hoke Smith, Athens, GA 30602

\author{
David A. Knauft ${ }^{3}$ \\ Department of Horticulture, University of Georgia, 1111 Miller Plant \\ Sciences Building, Athens, GA 30602
}

Additional index words. apomixis, Mendelian inheritance, pleiotropy, self-compatible

\begin{abstract}
American beautyberry (Callicarpa americana) is a deciduous shrub native to the southeast United States and is grown primarily for its metallic-purple fruit that develop in the fall. There are also pink- and white-fruiting and variegated forms but these traits are rare in nature and there is no information available regarding their inheritance. Also, there is confusion regarding self-compatibility and the presence of apomixis in Callicarpa L. Crosses were performed to investigate the genetics of fruit color, self-compatibility, and apomixis in american beautyberry. Test crosses between $C$. americana (CA) and $C$. americana 'Lactea' (CAL) suggested that white fruit is recessive to purple. White fruit appears to be controlled by a single recessive gene for which we propose the name white fruit and the gene symbol wft. Although there were only a limited number of progeny grown, crosses between CA and 'Welch's Pink' suggest that purple is dominant to pink. Test crosses between CAL and 'Welch's Pink' are needed to draw conclusions; however, we propose that purple, pink, and white fruit are controlled by an allelic series for which we suggest the gene symbols $W f t>w f t^{p}>w f t$. Segregation ratios suggested that all progeny in the study developed through sexual hybridization. All genotypes used in the current study were self-compatible.
\end{abstract}

Callicarpa $\mathrm{L}$. is a genus of $\approx 150$ species of shrubs and trees distributed throughout the world including warm-temperate and tropical America, southeast Asia, the Pacific Islands, and Australia (Harden, 1992) with the greatest concentration of species found in southeast Asia, specifically the Philippine Islands (Atkins, 1999). There are $\approx 28$ New World species, of which 16 are endemic to Cuba (Moldenke, 1936). The native distribution of american beautyberry (C. americana L.) in the United States ranges from Maryland in the north, west to Missouri, and south along the Gulf Coast from south Texas to Florida (USDA, 2012). American beautyberry produces a berry-like drupe in axillary cymes that

\footnotetext{
Received for publication 20 Dec. 2013. Accepted for publication 31 Jan. 2014.

We thank Nancy Hand and Bruce Tucker for technical assistance.

${ }^{1}$ Assistant Professor.

${ }^{2}$ Professor.

${ }^{3}$ Emeritus Professor.

${ }^{4}$ To whom reprint requests should be addressed; e-mail contrery@hort.oregonstate.edu.
}

R. Br. produced viable seed after selfpollination in a glasshouse (personal observation; unpublished data). Populations resulting from open-pollination of C. dichotoma 'Issai' or C. americana 'Welch's Pink' were very uniform, appearing almost clonal (M. Dirr, personal communication). This anecdotal lack of diversity in seedling populations suggests apomixis or homozygous parent plants because either self- or crosspollination of heterozygous parents should result in variation from the parental type (Ozias-Akins, 2006). Tsukaya et al. (2003) confirmed that $C$. Xshirasawana Makino is a natural hybrid resulting from the cross $C$. japonica $\times C$. mollis Sieb. et Zucc. and its fertility was confirmed by pollen staining and seed germination of the $F_{1}$ as well as successful back-crossing to $C$. japonica (Tsukaya et al., 2003). These results indicate that sexual reproduction exists in the genus and at least some level of outcrossing is observed.

The goal of the current research was to use controlled crosses to investigate the genetics of fruit color in C. americana. Results of crosses and segregation ratios of progeny were also used for inference about apomixis and self-incompatibility in american beautyberry.

\section{Materials and Methods}

Plants of Callicarpa americana (Accession no. GEN08-0036), C. americana 'Lactea', and C. americana 'Welch's Pink' were maintained at the University of Georgia Tifton Campus in 11.4-L containers filled with substrate containing 8 pine bark: 1 sand amended with $0.91 \mathrm{~kg} \cdot \mathrm{m}^{-3}$ dolomitic lime and $0.45 \mathrm{~kg} \cdot \mathrm{m}^{-3}$ Micromax (The Scotts Co., Marysville, $\mathrm{OH}$ ) and top-dressed with $45 \mathrm{~g}$ of Osmocote Plus 15-4.0-9.1 (The Scotts Co.). The wild-type (GEN08-0036) was from a north Georgia provenance collected near Athens, GA. Controlled crosses were conducted in a glasshouse with day/night set temperatures of $27 / 20^{\circ} \mathrm{C}$. For cross-pollination and emasculation only (EO) treatments, emasculation was performed at least $1 \mathrm{~d}$ before anthesis. For selfpollination, emasculation was not performed and pollen was applied to the stigma by direct contact with an anther of the same flower. For cross-pollination, pollen was collected by tapping inflorescences over a petri dish and was then applied to receptive stigmas of emasculated flowers using brushes. After ripening, fruit were scored as purple, pink, or white (Fig. 1), collected and counted, and then seed were cleaned by hand and counted. Seed were then subjected to cold, moist stratification at $4{ }^{\circ} \mathrm{C}$ for $60 \mathrm{~d}$ and sown in the same pine bark substrate as described previously. Controlled crosses performed to investigate fruit color may be found in Table 1. In addition to these crosses, 113 flowers of CA were subjected to EO to determine if pollination was necessary for fruit development. Chi square analysis was conducted to test for goodness of fit to theoretical ratios (PROC FREQ; SAS Version 9.1; SAS Institute Inc., Cary, NC). 

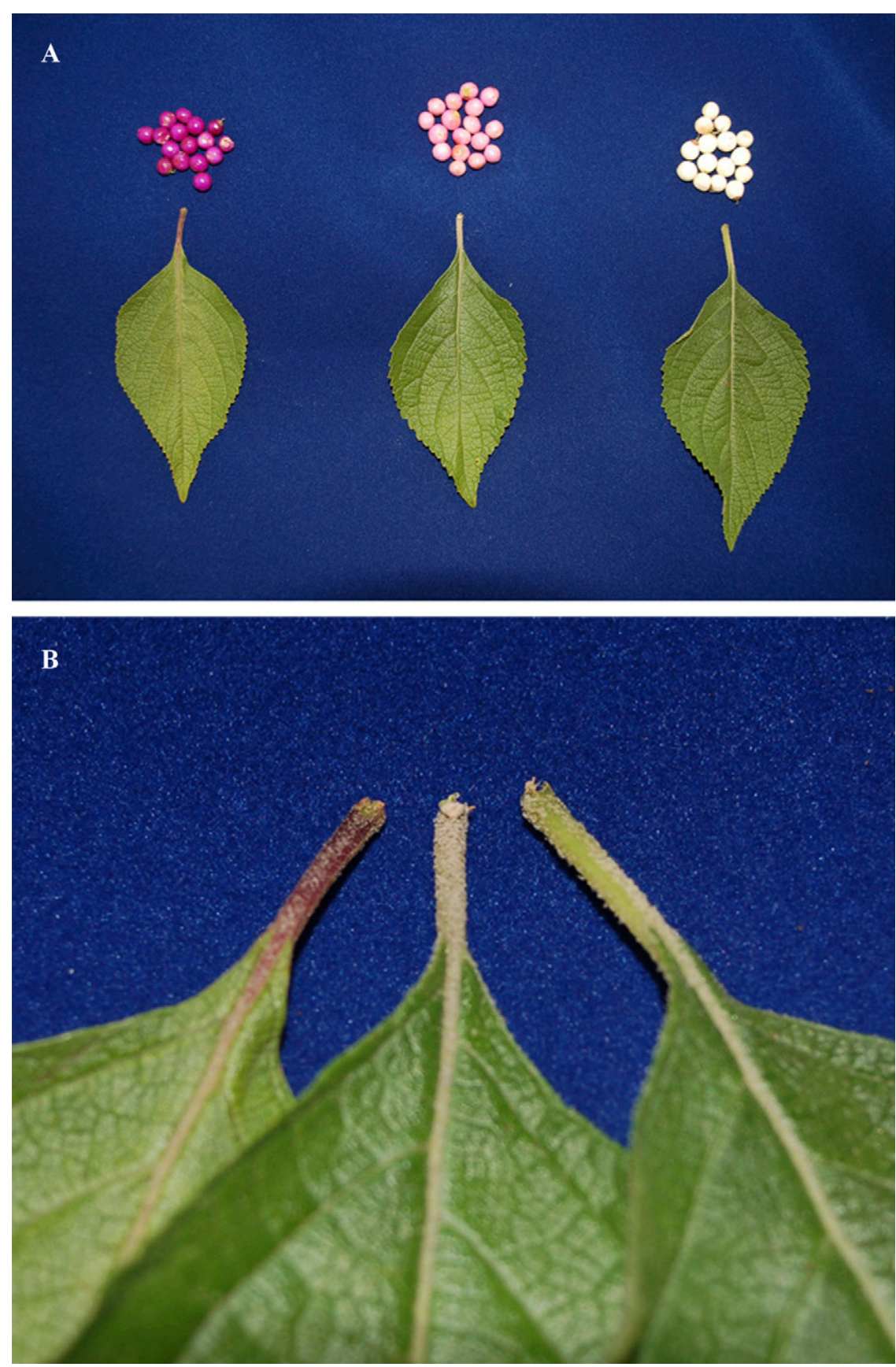

Fig. 1. The three phenotypic classes (purple, pink, and white, from left to right) of Callicarpa americana (A) for fruit and petiole color and (B) closeup of petiole color.

\section{Results}

Fruit color. All progeny resulting from self-pollination of CA and CAL had fruit that were purple and white, respectively (Table 1) suggesting that both are homozygous for fruit color alleles. Reciprocal crosses between CA and CAL yielded all purple fruit with the exception of four white individuals that were obtained when CAL was used as the pistillate parent and are likely the result of selfpollination, because each fruit contains four seeds. These four individuals were not included in $\chi^{2}$ analysis. Both $\mathrm{F}_{2}$ families fit the expected $3: 1$ ratio $\left(\mathrm{F}_{2 \mathrm{P} 1} P=0.50 ; \mathrm{F}_{2 \mathrm{P} 2} P=\right.$ $0.48)$ and all three back-cross $(\mathrm{BC})$ families fit the expected $1: 1$ ratio $\left[\left(\mathrm{BC}_{1 \mathrm{P} 1} P=0.32\right.\right.$; whereas individuals with white flowers had white fruit. Flower color was not recorded for plants with pink fruit but we noted flower color was lighter in 'Welch's Pink' than in the wild type. The lack of segregation among flower, fruit, and petiole color suggests that they are likely controlled by a single pleiotropic gene or possibly by two very tightly linked genes.

Self-compatibility and apomixis. Selfpollination of $C$. americana in a glasshouse produced viable seed indicating selfcompatibility. The 113 flowers subjected to EO treatment produced only 0.3 seed per emasculated flower (data not shown), which was lower than for pollination treatments (2.9 seed per pollinated flower). The seed produced from EO treatment is likely to be produced from accidental cross-pollination or self-pollination, because growth in american beautyberry is indeterminate and flowers receiving EO treatment were below newly expanding flowers above. Furthermore, segregation for purple fruit pigmentation in $\mathrm{F}_{2}$ and $\mathrm{BC}$ families is indicative of sexual recombination as opposed to apomixis.

\section{Discussion}

Progeny showed neither variation in intensity of purple fruit color nor intermediates between purple and white or purple and pink color. This supports the conclusion that complete dominance in the gene controlling fruit color. In contrast, Honda et al. (1990) present evidence that fruit color in beefsteak plant (Perilla frutescens Britton) is controlled by a single incomplete dominant gene $(W)$ that results in three phenotypic classes with white being recessive. Mature fruit color in Capsicum annum $\mathrm{L}$. is reported to be controlled by three genes, which also show complete dominance, identified genetically as $\mathrm{yyc}_{1} \mathrm{c}_{1} \mathrm{c}_{2} \mathrm{c}_{2}$ (Shifriss and Pilovsky, 1992). Fruit color is controlled by two genes with dominant epistasis in summer squash [(Cucurbita pepo L.) (Globerson, 1969)] and hybrid grapes [(Vitis spp. L.) (Barritt and Einset, 1969)]. In both examples, white fruit is recessive and is identified as ccrr in summer squash (Globerson, 1969) and bbrr in grapes (Barritt and Einset, 1969). In the current study, white fruit color appears to be controlled by a single recessive gene for which we propose the name white fruit and the symbol $w f t$. The lack of intermediates among the three classes (purple, pink, white) suggests that there are three alleles for fruit color. All progeny $\left(F_{1}, F_{2}\right.$, and $\mathrm{BC}$ families) have shown that purple is dominant to white, and a limited number of progeny tested indicate that purple is dominant to pink. We propose the gene symbols for the allelic series controlling fruit color as $W f t>w f t^{\mathrm{p}}>w f t$ for purple (wild-type), pink, and white fruit, respectively.

Flower, petiole, and fruit color cosegregated in all $\mathrm{F}_{1}, \mathrm{~F}_{2}$, and $\mathrm{BC}$ families suggesting either a single pleiotropic gene or tight linkage between genes controlling these traits. Dirr (2009) also noted a correlation between flower and fruit color in american beautyberry. 
Table 1. Controlled crosses among Callicarpa americana (CA), C. americana 'Lactea' (CAL), and C. americana 'Welch's Pink' (CWP) to determine inheritance of fruit color based on segregation of the number of wild-type, purple individuals ( $\left.\mathrm{Wft} /{ }_{-}\right)$and white individuals ( $\left.w f t / w f t\right) .{ }^{\mathrm{z}}$

\begin{tabular}{|c|c|c|c|c|c|c|}
\hline \multirow[b]{2}{*}{ Cross $(q \times \widehat{\jmath})$} & \multirow[b]{2}{*}{ Families } & \multicolumn{2}{|c|}{ Progeny (no. plants) } & \multirow[b]{2}{*}{ Exp. ratio } & \multirow[b]{2}{*}{$\chi^{2 y}$} & \multirow[b]{2}{*}{$P$} \\
\hline & & $W f t /$ & $w f t / w f t$ & & & \\
\hline CA selfed & $\mathrm{S}_{0}$ & 65 & 0 & $1: 0$ & 0.00 & 1.00 \\
\hline CAL selfed & $\mathrm{S}_{0}$ & 0 & 46 & $0: 1$ & 0.00 & 1.00 \\
\hline $\mathrm{CA} \times \mathrm{CAL}$ & $\mathrm{F}_{1 \mathrm{P} 1}$ & 114 & 0 & $1: 0$ & 0.00 & 1.00 \\
\hline $\mathrm{CAL} \times \mathrm{CA}$ & $\mathrm{F}_{1 \mathrm{P} 2}$ & 88 & $4^{x}$ & $1: 0$ & 0.00 & 1.00 \\
\hline $\mathrm{F}_{1 \mathrm{P} 1}$ selfed & $\mathrm{F}_{2 \mathrm{P} 1}$ & 34 & 14 & $3: 1$ & 0.44 & 0.50 \\
\hline $\mathrm{F}_{1 \mathrm{P} 2}$ selfed & $\mathrm{F}_{2 \mathrm{P} 2}$ & 23 & 10 & $3: 1$ & 0.49 & 0.48 \\
\hline $\mathrm{F}_{1 \mathrm{P} 1} \times \mathrm{CAL}$ & $\mathrm{BC}_{1 \mathrm{P} 1}$ & 15 & 21 & $1: 1$ & 1.00 & 0.32 \\
\hline $\mathrm{F}_{1 \mathrm{P} 2} \times \mathrm{CAL}$ & $\mathrm{BC}_{1 \mathrm{P} 2}$ & 10 & 12 & $1: 1$ & 0.18 & 0.67 \\
\hline $\mathrm{CAL} \times \mathrm{F}_{1 \mathrm{P} 2}$ & $\mathrm{BC}_{2 \mathrm{P} 2}$ & 10 & 10 & $1: 1$ & 0.00 & 1.00 \\
\hline $\mathrm{CWP} \times \mathrm{CA}$ & $\mathrm{F}_{1 \mathrm{P} 4}$ & 12 & 0 & $1: 0$ & 0.00 & 1.00 \\
\hline
\end{tabular}

${ }^{\mathrm{z}}$ Chi square expected ratios are based on the assumption of complete dominance of the purple allele. ${ }^{\mathrm{y}} \chi^{2}{ }_{0.05,1}=3.841$.

${ }^{\mathrm{x}}$ Unexpected phenotype that deviates from disomic-monogenic model, likely the result of accidental selfpollination. These data not included in $\chi^{2}$ analysis

Pleiotropic genes controlling pigment production in multiple organs were described previously by Evans et al. (1984), who reported the tangerine-virescent (tv-tc1) character in tomato that results in orange flowers and fruit and yellow virescent leaves is controlled by a single recessive allele. Linkage cannot be ruled out completely; however, the lack of recombinant progeny makes pleiotropy a more likely scenario. The cosegregation of petiole and fruit color may be a useful tool in early screening of american beautyberry progeny.

We used an EO treatment and reciprocal crosses between white- and purple-fruited plants to determine if apomixis is present in american beautyberry. The EO treatment resulted in reduced fruit and seed set. The fruit and seed that were produced after emasculation are likely the result of accidental self- or cross-pollination. These results suggest that pollination is required for seed set. Additionally, the fact that $F_{1}, F_{2}$, and $B C$ families fit the expected Mendelian segregation ratios for fruit color and provides further evidence that all progeny resulted from sexual reproduction. Ozias-Akins (2006) indicated that

controlled crosses using a simply inherited trait such as pigmentation of various organs as used in the current study are an effective means for determining the relative rates of apomixis vs. amphimixis. This technique has been used to assess apomixis among hybrids involving pearl millet [Pennisetum glaucum (L.) R. Br.] and P. squamulatum Fresen. (Roche et al., 2001) using the single dominant gene $\mathrm{Rp}^{1}$ for red leaf (Hanna and Burton, 1992).

Our data provide evidence supporting an allelic series for fruit color in american beautyberry. We propose the symbols for purple, pink, and white fruit as $W f t>w f t^{\mathrm{p}}>$ $w f t$. Furthermore, our data suggest that the gene controlling fruit color is pleiotropic and also controls flower and petiole color. Test crosses and emasculation also suggested that all of the progeny produced in the current study developed through sexual hybridization and that all genotypes used in the study were self-compatible.

\section{Literature Cited}

Atkins, S. 1999. Callicarpa japonica: Labiatae. Curtis Bot. Mag. 16:79-83.
Barritt, B.H. and J. Einset. 1969. The inheritance of three major fruit colors in grapes. J. Amer. Soc. Hort. Sci. 94:87-89.

Dirr, M.A. 2009. Manual of woody landscape plants: Their identification, ornamental characteristics, culture, propagation and uses. 6th Ed. Stipes, Champaign, IL.

Evans, D.A., W.R. Sharp, and H.P. Medina-Filho. 1984. Somaclonal and gametoclonal variation. Amer. J. Bot. 71:759-774.

Globerson, D. 1969. The inheritance of white fruit and stem color in summer squash, Cucurbita pepo L. Euphytica 18:249-255.

Hanna, W.W. and G.W. Burton. 1992. Genetics of red and purple plant color in pearl millet. J. Hered. 83:386-388.

Harden, G.J. (ed.). 1992. Flora of New South Wales. Vol. 3. New South Wales University Press, Kensington, New South Wales, Australia.

Honda, G., Y. Koezuka, and M. Tabata. 1990. Genetic studies of fruit color and hardness in Perilla frutescens. Jpn. J. Breeding 40:469474.
Kawakubo, N. 1990. Dioecism of the genus Callicarpa (Verbenaceae) in the Bonin (Ogasawara) islands. Bot. Mag. Tokyo 103:57-66.

Moldenke, H.N. 1936. A monograph of the genus Callicarpa as it occurs in America and in cultivation. Feddes Repert. 39:288-317.

Ozias-Akins, P. 2006. Apomixis: Developmental characteristics and genetics. Crit. Rev. Plant Sci. 25:199-214.

Roche, D., Z. Chen, W.W. Hanna, and P. OziasAkins. 2001. Non-Mendelian transmission of an apospory-specific genomic region in a reciprocal cross between sexual pearl millet (Pennisetum glaucum) and an apomictic F1 $(P$. glaucum $\times P$. squamulatum $)$. Sex. Plant Reprod. 13:217-223.

Shifriss, C. and M. Pilovsky. 1992. Studies of the inheritance of mature fruit color in Capsicum annuum L. Euphytica 60:123-126.

Tsukaya, H., T. Fukuda, and J. Yokoyama. 2003. Hybridization and introgression between $\mathrm{Cal}$ licarpa japonica and C. mollis (Verbenaceae) in central Japan, as inferred from nuclear and chloroplast DNA sequences. Mol. Ecol. 12: 3003-3011.

USDA, NRCS. 2012. The PLANTS database. National Plant Data Center, Baton Rouge, LA. 27 Jan. 2014. <http://plants.usda.gov>. 